\title{
Risk-benefit and cost-utility analysis for COVID-19 lockdown in Belgium: the impact on mental health and wellbeing.
}

Frederik Feys ${ }^{1}$, Sam Brokken ${ }^{2}$, Steven De Peuter ${ }^{3}$

${ }^{1} \mathrm{PhD}$ Medical Sciences, Independent researcher Antwerp, Belgium

${ }^{2}$ MSc Public Health, Independent researcher. Leuven, Belgium

${ }^{3} \mathrm{PhD}$ Health Psychology, Independent researcher, Leuven, Belgium 


\section{Abstract}

\section{OBJECTIVE}

The objective of this study was to assess the benefits and risks of a lockdown in Belgium, with focus on mental health. Consequently, projecting the cost effectiveness of remedial measures.

\section{METHODS}

For benefits; in estimating health savings, we compared Belgium (lockdown) and Sweden (lockdown-light) for COVID-19 related deaths, peak intensive care unit load and peak hospitalisations load. We also calculated the years of life lost (YLL). For risks; we assessed the mental health and wellbeing, using the most common dimensions: anxiety and depression. GAD-7 and PHQ-9 scores were extracted from a survey and compared to a similar representative survey in 2018. Disability-adjusted life years (DALYs) were calculated for and we assessed non-COVID-19 related-deaths from excess mortality. Cost-utility analysis was performed with a 1-year time horizon. Hence, considering the Quality-adjusted Life Years (QALYs), Incremental Cost-effectiveness Ratio (ICER) and the potential impact providing adequate treatment compared to standard care.

\section{RESULTS}

Lockdown versus lockdown-light gave no COVID-19 related benefits. COVID-19 related risks during lockdown saw an increase of 4,231 deaths; 667 extra ICU 
admissions on peak day, 3213 extra hospital admissions on peak day and 140 extra non-COVID-19 related deaths. Additionally, 140 extra deaths occured due to a non-COVID-19 cause. 1,034,365 (9,0\%) of Belgian population reported increased anxiety and/or depression. Risk-benefit analysis; COVID-19 related deaths yielded an extra 3,145 YLL, total psychological burden of $104,515(74,025-139,762)$ DALYs and the total loss of societal value is considered between $€ 3.0$ billion and $€ 5.6$ billion. Cost-utility analysis; ICER for psychological treatment for depression was $€ 11,510 / \mathrm{Q} A \mathrm{~L}$ gained. In total psychotherapy could create 181,714 $(34,134-213,654)$ QALYs and a 1 year net benefit of $€ 5.2$ billion.

\section{CONCLUSION}

We found no evidence that a lockdown versus lockdown-light results in less COVID-19 related mortality and morbidity. The Belgian lockdown created an obvious $+104,515(74,025-139,762)$ DALYs psychological burden in Belgium. Adequate investment in psychological help would provide individual relief and may improve a person's immunological response. Also, within a 1-year time horizon, taking into account the loss of value in healthy functioning people, the net benefit is $€ 0.9$ billion.

keywords: COVID-19, Belgium, Public Mental Health, Cost-Benefit Analysis, Quality-Adjusted Life Years 


\section{INTRODUCTION}

Rarely does an incident like the new SARS-CoV-2 virus lead to such an impact on a global scale. As in other countries, Belgian society locked-down on March 18th, 2020. The government wanted to safeguard the health system from a COVID-19 patient overflow, therefore limiting the number of potential deaths $\left({ }^{1}\right)$.

On March 3th, 2020, the WHO stated 3.4\% of global COVID-19 cases would face death - the so-called case fatality rate (CFR) - in comparison to $1 \%$ fatalities noted in those infected in an average seasonal flu season (influenza) $\left(^{2}\right)$. This statement led to an unintentionally induced worldwide panic reaction. In Western countries, influenza leads to less than $0.2 \%$ of case fatalities within the population every year, the so-called mortality rate $\left({ }^{3}\right)$. The $\mathrm{WHO}$ uses the case fatality rate (CFR) to classify these data. However these are prone to evolve in misleading statistics. The CFR is dependable on whom gets tested and the number of tests carried out by health authorities. Also, the CFR is highly dependent on the case-definition used and of the evolved time between the start of the epidemic and obtaining the results $\left({ }^{4}\right)$. Hence, the CFR does not inform about the SARS-CoV-2 virus mortality potential. Nevertheless, the number of cases and deaths based on this CFR have been spiralling through all media channels on a minute-to-minute basis. 
March 16th, 2020; a British scientific report from the Imperial College predicted a major death toll if the government would not implement a full-lockdown. A non-peer reviewed predictive model based on a lockdown-light scenario encompassing a variety of assumptions concluded nearly 250,000 deaths would occur in the UK $\left({ }^{5}\right)$. Moreover, Ferguson and colleagues assumed an infection fatality rate (IFR) of $0.9 \%$ on average, solely based on a subset of data retrieved from China. This posed several extrapolation problems. Contrary to the CFR, an IFR also calculates for asymptomatic and undiagnosed cases $\left({ }^{6,7}\right)$. As not all governments use the same methodological approach in registering and analysing data, conclusions may be vulnerable for biases $\left({ }^{8}\right)$. In China (like Africa and Latin America), far more elderly people die of influenza than in Western countries $\left(^{3}\right)$, resulting in a higher IFR. We may assume this demographic distribution led to a higher CFR/IFR for the new SARS-CoV-2 virus. Hence, not being representative for other countries. Currently there are no data supporting theories projecting a higher death-rate for SARS-CoV-2 virus in comparison to influenza. Exact figures on influenza mortality are often prone to assumptions and clustered registrations. The GLaMOR Project estimated 389,000 influenza-deaths per year $(95 \% \mathrm{Cl}$ $294,000-518,000)$ worldwide $\left({ }^{3}\right)$ during a non-endemic season. During the writing of this article, 254,375 COVID-19 related deaths were accounted for globally $\left({ }^{9}\right)$.

Many countries chose for a suppression strategy to spread out the stress on their health care capacity. Consequently, most countries seemed able to cope with the number of hospital admissions and intensive care demands. However, 
populations worldwide are currently being deprived from their personal liberties leading to a contentious situation. For one, the psychological impact of a lockdown (imposed self-quarantine) is wide-ranging, substantial, and may pose a long lasting burden on population health $\left({ }^{10}\right)$. The mental health of the population also determines the risk of illness, death after infection, and the vaccine efficacy $\left({ }^{11-13}\right)$. Also, increased mass stress induced by a lockdown will lower immunity levels, inducing increased morbidity and mortality. Of particular concern are also the non-COVID-19 related deaths, which may arise from new suicides, delayed health care interventions and overall impact of declining social determinants leading to a higher degree of health inequalities $\left({ }^{14,15}\right)$. A systematic review by Patel et al. $\left({ }^{16}\right)$ concluded mental health declined on average by $20 \%$ in populations with widening income-gaps as a consequence of increased poverty.

This study aims to perform a risk-benefit analysis after 57 days of lockdown in Belgium. We are interested in the potential of lives saved in comparison to a lockdown-light scenario $\left({ }^{17}\right)$ and the potential impact of the lockdown on mental health. We also want to know what investments would be suitable in mitigating the potential mental burden. We believe mental health is underexposed in policy making and lacks recognition by the Belgian government and the National Security Council. Nonetheless, the mental-immunological connection may be a crucial dimension of potential public health burden during this crisis. 


\section{Methods}

Data were retrieved in government public health agencies reports; census reports and national statistics databases $\left({ }^{18-20}\right)$. If not available or if further clarifications were needed, we contacted agencies by email (table 1; Appendix 1, provides an overview with results). From March 23th, 2020 till May 12th, 2020, we had 43 contacts by email. 26 requesting data, 3 on followups; 2 requesting full text access; 3 regarding additional methodological information, 3 peer advices; 5 informing about relevant studies. 11 of these contacts yielded a helpful answer. Contacts that provided the most helpful answers were fellow scientists (6). Helpful response rate was the highest for fellow scientists at Governmental Public Health (5 of 8 contacts). Of all the helpful answers, the data and collaboration requests were most often helpful (table 2; Appendix 1).

\section{Benefits}

Data search was restricted to short-term benefits. Long-term benefits (e.g. better air quality), which may be beneficial for people with chronic diseases, were left out.

In estimating health savings; we compared Belgium and Sweden for COVID-19 related deaths, peak intensive care unit load and peak hospitalisation load. The two countries are relatively comparable in terms of proportion of elderly people (aged $\geq 80$ ): $5.64 \%$ and $5.19 \%$, access to health care: universal and automatic and by degree of urbanisation: $98.00 \%$ and $87.43 \%$ respectively 
$\left({ }^{21}\right)$. The proportion of elderly people is the most important driver of COVID-19 deaths $\left({ }^{22}\right)$ so we statistically corrected the data. Belgium is under lockdown and the government imposes its population to self-quarantaine. Sweden implemented a lockdown-light, and is considered the reference country. Lockdown-light implies that society runs as normal with some voluntary advices (no enforcement): preventative hand hygiene, no gatherings of more than 50 people, social distancing in crowded spaces, home-based work, no school or preschool when slightly unwell, distance learning in higher education, abstaining from hospital and care home visit $\left({ }^{23}\right)$. Lockdown encompasses the same measures, but enforced by the government. Moreover, gatherings are prohibited; home-based work is enforced and non-home-based-work is restricted to essential societal drivers (e.g. food supply, distribution, primary care). We assume that a full-lockdown will lead to benefits. Per 100,000 inhabitants we calculated the number of extra $(\geq 80$ aged corrected) COVID-19 related survivors; the number of saved peak demand intensive care units and the number of saved peak demand hospitalisations $\left({ }^{17,24}\right)$. In calculating the numbers of saved lives, we extrapolated and adjusted the rates to the Belgian situation $\left({ }^{25}\right)$. Furthermore, we calculated the years of life lost (YLL) with healthy life years (HLY) as a limit for life expectancy. In 2018, the HLY in Belgium stood at 63.8 years for women and 63.2 years for men. 


\section{RISKS}

Assessing the mental health and wellbeing, we focussed on the most common dimensions: anxiety and depression. Reference figures were constructed using the Sciensano Health Survey $2018\left({ }^{26}\right)$, a Belgian representative study. This survey used the GAD-7 (General Anxiety Disorder-7), a screening tool and symptom severity measure for the four most common anxiety disorders: Generalised Anxiety Disorder, Panic Disorder, Social Phobia and PostTraumatic Stress Disorder $\left({ }^{27}\right)$. The latter was supported by the PHQ-9 (Patient Health Questionnaire-9): a screening tool and symptom severity measure for depression which is part of the major depressive disorder (MDD) module of the full PHQ $\left.{ }^{28}\right)$. We could not retrieve mental health and wellbeing data for Sweden.

The lockdown mental burden was screened by the first Sciensano Health Survey COVID-19 $\left({ }^{29}\right)$, also using the GAD-7 and the PHQ-9. Hence, calculating and comparing new cases with the 2018 survey were feasible. The surveyed period is approximately 3 weeks after lockdown. Around 44,000 Belgians participated. The socioeconomic status from this sample was higher than in the general population. As comorbidity is common within anxiety and depression disorders $\left({ }^{30}\right)$, we minimised overlap by separating into 3 categories: anxiety, depression, and depression and anxiety.

We calculated disability-adjusted life years (DALYs) with $95 \% \mathrm{Cl}$ based on the Global Burden of Disease 2017 rates. 
From the DALYs; assuming a healthy life year is worth EUR 40,000 per DALY $\left.{ }^{(32}\right)$, we calculated an estimated societal loss of life value in financial terms.

We assessed non-COVID-19 related-deaths from excess mortality; monitored by the Belgian Mortality Monitor $\left({ }^{33}\right)$ and Swedish SCB $\left({ }^{34}\right)$, calculated the YLL: non-COVID-19 related deaths $=$ total excess mortality minus COVID-19 related deaths. We contacted the relevant Belgian government agencies for data on death certificates to assess non-COVID-19 related-deaths population characteristics.

\section{Cost-UtiLity ANALYSIS}

With a 1-year time horizon, we calculated QALYs gained when people suffering from mental problems would have adequate treatment compared to usual care or waiting lists. We constructed parameters (Appendix 2, full specification of the analysis) such as: utility for usual care as 1 minus age standardised disability weight. We used published disability weights corresponding to mild anxiety and mild depression $\left({ }^{31}\right)$.The utility for treatments were based on treatment effectiveness in terms of quality of life; costs associated with each treatment option, mean QALYs gained; incremental costs, incremental QALYs, ICER, and the net benefit (QALY $x$ willingness-to-pay) minus incremental cost. We searched for evidence of any treatment that effectively improved quality of life at 1 year or longer. 


\section{Sensitivity ANALYSis}

We used the Disability-Free Life Expectancy (DFLE) as a limit, considering this is the most frequently used benchmark in Belgian reports. For Belgium the DFLE is projected at 74 years $\left({ }^{35}\right)$.

\section{RESULTS}

\section{Benefits}

Lockdown versus lockdown-light gave no benefits.

\section{RISKS}

\section{COVID-19 related}

Lockdown versus lockdown-light accounts for 37 extra deaths per 100,000 people. On the peak ICU occupation day, an extra 5.40 per 100,000 ICU beds were needed. On the peak hospitalisations day, 28.11 per 100,000 extra hospital admissions were estimated. Belgium had an extra 4,231 COVID-19 related deaths. On its peak day, in lockdown an extra of 727 ICU and 3459 hospitalisations were counted (Table 1).

During Belgian lockdown, 140 extra deaths occurred related to non-COVID-19 causes. The Sciensano survey mentioned that at least $60 \%$ of the appointments for medical care (general practitioner, psychological help, medical-technical treatment, medical-technical examination, medical specialist 
or rehabilitation) were canceled or postponed. $42 \%$ of home nurse services had stopped or reduced their activities.

\begin{tabular}{|c|c|}
\hline \multicolumn{2}{|r|}{ Table 1 Benefits and risks of lockdown Belgium } \\
\hline \multicolumn{2}{|r|}{ Benefits (compared to lockdown-light) } \\
\hline \multicolumn{2}{|r|}{ none found } \\
\hline \multicolumn{2}{|r|}{ Risks (compared to lockdown-light) } \\
\hline \multicolumn{2}{|r|}{ compared to lockdown-light } \\
\hline \multicolumn{2}{|l|}{ COVID-19 related } \\
\hline & difference $\mathbf{N}$ \\
\hline $\begin{array}{l}\text { COVID-19 related } \\
\text { deaths }\end{array}$ & $+4,231$ \\
\hline $\begin{array}{l}\text { ICU admissions on peak } \\
\text { day }\end{array}$ & +667 \\
\hline $\begin{array}{l}\text { hospital admissions on } \\
\text { peak day }\end{array}$ & +3213 \\
\hline $\begin{array}{l}\text { non-COVID-19 related } \\
\text { deaths }\end{array}$ & +140 \\
\hline \multicolumn{2}{|r|}{ compared to 2018} \\
\hline Psychological suffering & \\
\hline
\end{tabular}




\begin{tabular}{|l|l|l|l|l|}
\hline & $\begin{array}{l}\text { difference } \\
\mathbf{N}\end{array}$ & trend \% & $\begin{array}{l}\text { lockdown } \\
\%\end{array}$ & $2018 \%$ \\
\hline anxiety & $\mathbf{+ 3 5 5 , 2 3 6}$ & $\mathbf{+ 7 7 . 0 \%}$ & $8.6 \%$ & $4.9 \%$ \\
\hline depression & $\mathbf{+ 1 5 7 , 6 7 2}$ & $\mathbf{+ 5 2 . 9 \%}$ & $4.8 \%$ & $3.1 \%$ \\
\hline depression and anxiety & $\mathbf{+ 5 2 1 , 4 5 7}$ & $\mathbf{+ 8 8 . 4 \%}$ & $11.7 \%$ & $6.2 \%$ \\
\hline total & $\mathbf{+ 1 , 0 3 4 , 3 6 5}\left(\mathbf{9 . 0} \%{ }^{*}\right)$ & \\
\hline
\end{tabular}

\section{Psychological suffering}

In lockdown, an additional 355,236 (trend $+77.0 \%$ ) individuals reported symptoms of anxiety disorder; 157,672 (trend $+52.9 \%$ ) more people reported symptoms of depression and 521,457 (trend $+88.4 \%$ ) more people reported symptoms of comorbid anxiety and depression.

The largest increase in psychological suffering is observed in the population of adolescents between ages 16 and 24 years. An increase was also noted in adults between 25-34 years, in people living alone (with or without children), for unemployed populations, disabled people and for people experiencing increased social suffering.

RISK-BENEFIT ANALYSIS

Table 2: Risks and benefits analysis lockdown Belgium: YLL and DALY YLL 


\begin{tabular}{|c|c|}
\hline COVID-19 related deaths & $+3,145$ \\
\hline \multirow[t]{2}{*}{ non-COVID-19 related deaths } & * \\
\hline & DALY $(95 \% \mathrm{Cl})$ \\
\hline anxiety & $+41,200(29,414-54,826)$ \\
\hline depression & $+14,700(10,357-19,719)$ \\
\hline anxiety and depression & $+48,615(34,254-65,216)$ \\
\hline $\begin{array}{l}\text { total new psychological } \\
\text { burden }\end{array}$ & $+104,515(74,025-139,762)$ \\
\hline total loss of value & $\begin{array}{l}€ 4,306,391,211 \\
(3,086,796,826-5,716,282,464)\end{array}$ \\
\hline
\end{tabular}

\section{Cost-UTILITY ANALYSIS}

For anxiety, we found no evidence of treatments with at least a 1 year quality of life outcome assessment. For depression or depression with comorbid anxiety, we found psychotherapy increased quality of life at 1 year or longer $\left.{ }^{(36}\right)$ In projecting a full analysis considering all new cases, we assumed individuals with anxiety would benefit equally well from psychotherapeutic treatment.

\begin{tabular}{|c|c|c|c|c|c|c|}
\hline \multicolumn{7}{|c|}{ Cost-utility analysis: 1 year horizon, societal perspective } \\
\hline strategy & $\begin{array}{l}\text { mean } \\
\text { costs, } \\
\text { million } \\
€\end{array}$ & $\begin{array}{l}\text { mean } \\
\text { QALYs } \\
(95 \% \mathrm{Cl})\end{array}$ & $\begin{array}{l}\text { increme } \\
\text { ntal } \\
\text { costs, } \\
\text { million } €\end{array}$ & $\begin{array}{l}\text { increment } \\
\text { al QALYs } \\
(95 \% \mathrm{Cl})\end{array}$ & $\begin{array}{l}\text { ICER: } \\
\text { strategy } \\
\text { vs. usual } \\
\text { care, } \\
€ / Q A L Y \\
\text { gained }\end{array}$ & $\begin{array}{l}1 \text { year net } \\
\text { benefit, million } \\
€\end{array}$ \\
\hline \multicolumn{7}{|c|}{ Depression / anxiety } \\
\hline Usual care & 166.5 & $\begin{array}{l}718,184 \\
(607,674-\end{array}$ & - & - & - & - \\
\hline
\end{tabular}




\begin{tabular}{|l|l|l|l|l|l|l|}
\hline & & $820,711)$ & & & & \\
\hline Psychotherapy & $2,258.0$ & $\begin{array}{l}899,897 \\
(641,808- \\
1,034,365)\end{array}$ & $€ 2,091.5$ & $\begin{array}{l}0.198 \\
(-0.10-0.4)\end{array}$ & $€ 11,510$ & $€ 5,177,1$ \\
& & & \\
\hline
\end{tabular}

\section{Sensitivity ANALYSis}

Disability-Free Life Expectancy

Table 3: Risk and Benefits lockdown Belgium: YLL with DFLE limit

\begin{tabular}{|l|l|l|l|l|}
\hline & $\begin{array}{l}\text { YLL (DFLE } \\
\text { limit) }\end{array}$ & $\begin{array}{l}\text { YLL (HLY } \\
\text { limit) }\end{array}$ & \\
\hline & val & $\begin{array}{l}\text { \% of total new } \\
\text { DALYs }\end{array}$ & $\begin{array}{l}\% \text { of total new } \\
\text { DALYs }\end{array}$ \\
\hline $\begin{array}{l}\text { COVID-19 related } \\
\text { deaths }\end{array}$ & $+8,899$ & $7.8 \%$ & $+3,145$ & $2.9 \%$ \\
\hline
\end{tabular}

\section{Discussion}

\section{STATEMENT OF PRINCIPAL FINDINGS}

Contrary to our hypothesis, compared to a lockdown-light, a full lockdown had an extra 3,145 (2.9\% of total lockdown Belgian DALYs) loss of healthy life years.

The lockdown imposed a higher degree of mental burden of 104,515 $(74,025-139,762)$ DALYs $(97.1 \%$ of total lockdown Belgian DALYs). Younger people aged between 16-24, people living alone (with or without a child), unemployed people and disabled people suffered the most. 
We estimated Belgium's total loss of value in healthy functioning people ranging between $€ 3.1$ billion and $€ 5.7$ billion. $97.1 \%$ of this cost-share is directly related to anxiety and depression. If Belgium were to provide psychotherapeutic treatment for anxiety and depression with/without comorbid anxiety, after 1 year society would gain 181,714 (34,134-213,654) QALYs and reach benefits worth of $€ 5.2$ billion. Taking into account the loss of value in healthy functioning people, the net benefit will be $€ 0.9$ billion (-0.5 billion -2.1 billion).

Belgium has $1,818 \mathrm{ICU}$ beds and 65,845 hospital beds $\left({ }^{37}\right)$. On April, 8 th, the SARS-CoV-2 virus epidemic caused a peak-load of $1,285(70.7 \%$ of max capacity) ICU patients. Following the lockdown-approach, Belgium had 667 (missed a $63.3 \%$ max capacity situation) more ICU patients. On April, 6th, the outbreak caused a peak load of 5,759 (8.7\% of max capacity) hospitalisations while having 3,213 (missed a $3.9 \%$ max capacity situation) extra hospitalisations.

During Belgian lockdown, 140 extra deaths occured due to a non-COVID-19 cause.

Sensitivity analyses using the DLFE limit, showed a very small increase of YLL (+7.8\% of total lockdown DALYs). Compared to the HLY limit $(+2.9 \%$ of total lockdown DALYs), these differences did not impact our main findings.

Although our results suggest an extra 4,231 COVID-19 related deaths in lockdown, the impact on YLLs is low. This may be explained by several factors. The majority of COVID-19-related deaths are found in people aged 80 
years or older. Overall, the pandemic seems to cause a mild disease and many infected people experience no sickness at all, especially children $\left(^{7}\right)$. After infection, only those prone to comorbidities or those of old age seem to have a higher chance of developing severe health complications. Also, our analysis suggests that the effective reduction of deaths, lower ICU peak demand and less hospital admissions of a total lockdown over a lockdown-light is debatable.

We think the very high number of people who report anxiety and depression disorders may result from a strong concurrence of mutually reinforcing factors. A very high mental burden already existed before the pandemic struck our world. For Belgium, we already estimated 136,334 (96,560-182,315) DALYs lost in $2018\left({ }^{26}\right)$. A new, unknown and invisible virus undoubtedly triggers panic as was the case with the HIV virus; SARS, MERS and Swine-Flu $\left({ }^{38}\right)$. Combined with the stressful nature of the emergency response to the outbreak this enhances the problem. The presence of ambulances, law enforcing police surveillance, excessive television and social media coverage, people wearing face masks and other protective measures, and panicky government communication can all add to the anxiety. It reinforces an individual's perception that the situation is dangerous. Especially younger populations with smartphone addiction may have extra mental problems due to a constant stream of dramatic media updates $\left({ }^{39}\right)$. Online misinformation magnified by artificial intelligence algorithms that promote sensational news, can further magnify stress $\left({ }^{40}\right)$. All this mass panic creates a nocebo 
effect $\left({ }^{41,42}\right)$, were negative expectations of health outcomes further deteriorate mental health and may negatively influence the human immune system $\left({ }^{43}\right)$.

\section{Completeness AND APPLICABILITY}

As far as we know, this is the first risk-benefit analysis for COVID-19. We aimed to get a first rough idea of possible public health gains and harms by imposing a lockdown handling the SARS-CoV-2 virus epidemic. For the calculations of the non-COVID-19 related deaths YLLs, we found no data on causes of death. Therefore, non-COVID-19 related deaths were left out of the analysis. Because data were not available, other important mental dimensions of burden such as potential increase of child abuse, domestic violence and new addiction to alcohol or drugs were not accounted for but may increase the overall burden.

\section{Strength AND WeAKNesses}

Estimates based on country comparison remains difficult to assess towards a thorough risk-benefit analysis. Ideally, one would conduct a randomised split within a country to assess differences. Clearly, such endeavour would be ethically and practically impossible to pursue. Therefore; we relied on extrapolation on data available from Sweden and Belgium, countries that are socio-demographically comparable. This approach has its limits as other unknown variables may influence differences in COVID-19 related deaths, hospitalisations, and ICU use. 
Also; non COVID-19 related deaths may have resulted from missed care: fear of visiting the hospital, fear of SARS-CoV-2 infection and wanting to die at home out of fear of dying without family support. Additionally, long-term risks and subsequent costs have not been accounted for in this article. For example, we may assume excessive hygienic measures negatively influencing our immune system. As within the child population we may consequently see an increase of allergic immune responses in the forthcoming years $\left({ }^{43,44}\right)$. As we could not find relevant reliable data for the non-COVID-19 related deaths, we were unable to calculate estimates for lockdown and lockdown-light scenarios.

\section{FUTURE RESEARCH}

Mental health may be a key element reducing the mortality and morbidity during a pandemic. It would be essential to research the impact of additional psychological stress imposed during a lockdown on the human immune system. How does it affect pandemic parameters?

Public health encompasses many dimensions: preventing disease, prolonging life and improving quality of life. Thus, a further fundamental question needs elucidation: did a lockdown versus a lockdown-light during the SARS-CoV-2 virus outbreak harm or protect public health?

Apart from anxiety or depression, suicidal tendencies, child abuse, partner abuse, addiction and poverty are important indicators of psychological social wellbeing. Incorporating these in future risk benefit analysis would provide a more complete picture of the psychological impact of a lockdown. 


\section{Conclusion}

We found no evidence that a lockdown versus lockdown-light results in less COVID-19 related mortality and morbidity. Within a short period of lockdown, we found a large (3.4\%) increase in total Belgian burden caused by premature death and disability. Merely $0.1 \%$ is COVID-19 death related, whereas $3.3 \%$ from people with new depression and/or anxiety are noted. As psychological well being also positively influences the immune response of a population; when left untreated, a vast $1,034,365(+9.0 \%)$ of new individuals may be at higher risk of developing COVID-19 related illnesses, death after infection, and less vaccine efficacy. By definition; solidarity efforts should go out to people who suffer the most during the lockdown: young people aged between 16-24, people living alone (with or without a child), unemployed and disabled people. Adequate investments (€2,1 billion) into psychological help would provide individual relief from this crisis. Also within a 1 year time horizon, taking into account the loss value of healthy functioning people, the net benefit will be $€ 0.9$ billion (-0.5 billion - $€ 2.1$ billion).

\section{References}

1. Coronavirus: versterkte maatregelen. Belgium.be. Published March 24, 2020. Accessed May 12, 2020. https://www.belgium.be/nl/nieuws/2020/coronavirus_versterkte_maatregelen

2. WHO Director-General's opening remarks at the media briefing on COVID-19 3 March 2020. Accessed May 5, 2020.

https://www.who.int/dg/speeches/detail/who-director-general-s-opening-remarks -at-the-media-briefing-on-covid-19---3-march-2020

3. Paget J, Spreeuwenberg P, Charu V, et al. Global mortality associated with seasonal influenza epidemics: New burden estimates and predictors from the GLaMOR Project. J Glob Health. 2019;9(2):020421. doi:10.7189/jogh.09.020421 
4. Spychalski P, Błażyńska-Spychalska A, Kobiela J. Estimating case fatality rates of COVID-19. Lancet Infect Dis. 2020;0(0). doi:10.1016/S1473-3099(20)30246-2

5. Ferguson N, Laydon D, Nedjati Gilani G, et al. Report 9: Impact of Non-Pharmaceutical Interventions (NPIs) to Reduce COVID19 Mortality and Healthcare Demand.; 2020. doi:10.25561/77482

6. COVID-19 - Algemene informatie | Coronavirus Covid-19. Accessed May 14, 2020. https://covid-19.sciensano.be/nl/covid-19-algemene-informatie

7. COVID-19 situation reports: Situation report - 46. Accessed May 14, 2020. https://www.who.int/emergencies/diseases/novel-coronavirus-2019/situation-rep orts

8. Althubaiti A. Information bias in health research: definition, pitfalls, and adjustment methods. J Multidiscip Healthc. 2016;9:211-217. doi:10.2147/JMDH.S104807

9. Coronavirus Update (Live): 3,682,489 Cases and 254,375 Deaths from COVID-19 Virus Pandemic - Worldometer. Accessed May 5, 2020. https://www.worldometers.info/coronavirus/

10. Brooks SK, Webster RK, Smith LE, et al. The psychological impact of quarantine and how to reduce it: rapid review of the evidence. The Lancet. 2020;395(10227):912-920. doi:10.1016/S0140-6736(20)30460-8

11. Chida $Y$, Steptoe A. Positive psychological well-being and mortality: a quantitative review of prospective observational studies. Psychosom Med. 2008;70(7):741-756. doi:10.1097/PSY.0b013e31818105ba

12. Yang EV, Glaser R. Stress-associated immunomodulation and its implications for responses to vaccination. Expert Rev Vaccines. 2002;1(4):453-459. doi:10.1586/14760584.1.4.453

13. Zimmermann $P$, Curtis N. Factors That Influence the Immune Response to Vaccination. Clin Microbiol Rev. 2019;32(2). doi:10.1128/CMR.00084-18

14. Pickett KE, Wilkinson RG. Inequality: an underacknowledged source of mental illness and distress. Br J Psychiatry J Ment Sci. 2010;197(6):426-428. doi:10.1192/bjp.bp.109.072066

15. Beckfield J, Bambra C. Shorter lives in stingier states: Social policy shortcomings help explain the US mortality disadvantage. Soc Sci Med 1982. 2016;171:30-38. doi:10.1016/j.socscimed.2016.10.017

16. Patel V, Burns JK, Dhingra M, Tarver L, Kohrt BA, Lund C. Income inequality and depression: a systematic review and meta-analysis of the association and a scoping review of mechanisms. World Psychiatry Off J World Psychiatr Assoc WPA. 2018;17(1):76-89. doi:10.1002/wps.20492

17. Analys och prognoser om pandemin covid-19 - Folkhälsomyndigheten. Accessed May 12, 2020. http://www.folkhalsomyndigheten.se/smittskydd-beredskap/utbrott/aktuella-utbro tt/covid-19/analys-och-prognoser/

18. Global Health Data Exchange | GHDx. Accessed May 13, 2020. http://ghdx.healthdata.org/

19. Statbel, het Belgische statistiekbureau | Statbel. Accessed May 5, 2020. https://statbel.fgov.be/nl

20. Statistics Sweden. Statistiska Centralbyrån. Accessed May 14, 2020. http://www.scb.se/en/ 
21. World Bank Group - International Development, Poverty, \& Sustainability. World Bank. Accessed May 14, 2020. https://www.worldbank.org/

22. Ioannidis JPA, Axfors C, Contopoulos-loannidis DG. Population-level COVID-19 mortality risk for non-elderly individuals overall and for non-elderly individuals without underlying diseases in pandemic epicenters. medRxiv. Published online May 5, 2020:2020.04.05.20054361. doi:10.1101/2020.04.05.20054361

23. The Public Health Agency of Sweden - The Public Health Agency of Sweden. Accessed May 13, 2020.

http://www.folkhalsomyndigheten.se/the-public-health-agency-of-sweden/

24. Corona-viruset: Slik spres viruset i Norge og verden. Kart og statistikk. VG Nett. Accessed May 9, 2020. https://www.vg.no/spesial/2020/corona/

25. COVID-19 - Epidemiologische situatie | Coronavirus Covid-19. Accessed May 9, 2020. https://covid-19.sciensano.be/nl/covid-19-epidemiologische-situatie

26. Gezondheidsenquête - Volledige_rapporten_2018. Accessed May 5, 2020. https://his.wiv-isp.be/nl/SitePages/Volledige_rapporten_2018.aspx

27. Spitzer RL, Kroenke K, Williams JBW, Löwe B. A brief measure for assessing generalized anxiety disorder: the GAD-7. Arch Intern Med. 2006;166(10):1092-1097. doi:10.1001/archinte.166.10.1092

28. Kroenke K, Spitzer RL, Williams JB. The PHQ-9: validity of a brief depression severity measure. J Gen Intern Med. 2001;16(9):606-613. doi:10.1046/j.1525-1497.2001.016009606.x

29. Sciensano 1ste Gezondheidsenquête COVID-19. https://www.sciensano.be/sites/www.wiv-isp.be/files/report_final_nl_0.pdf

30. Assmann N, Schramm E, Kriston L, et al. Moderating effect of comorbid anxiety disorders on treatment outcome in a randomized controlled psychotherapy trial in early-onset persistently depressed outpatients. Depress Anxiety. 2018;35(10):1001-1008. doi:10.1002/da.22839

31. Salomon JA, Haagsma JA, Davis A, et al. Disability weights for the Global Burden of Disease 2013 study. Lancet Glob Health. 2015;3(11):e712-e723. doi:10.1016/S2214-109X(15)00069-8

32. QALY: kosten en baten van de nieuwe behandelingen | Novartis België. Accessed May 11, 2020.

https://www.novartis.be/nl/stories/lacces-linnovation/qaly-kosten-en-baten-van-d e-nieuwe-behandelingen

33. Cox $B$, Wuillaume $F$, Van Oyen $H$, Maes $S$. Monitoring of all-cause mortality in Belgium (Be-MOMO): a new and automated system for the early detection and quantification of the mortality impact of public health events. Int $J$ Public Health. 2010;55(4):251-259. doi:10.1007/s00038-010-0135-6

34. Highest mortality this millennium noted in Sweden. Statistiska Centralbyrån. Accessed May 14, 2020.

http://www.scb.se/en/About-us/news-and-press-releases/highest-mortality-thismillennium-noted-in-sweden/

35. Renard F, Devleesschauwer B, Van Oyen H, Gadeyne S, Deboosere P. Evolution of educational inequalities in life and health expectancies at 25 years in Belgium between 2001 and 2011: a census-based study. Arch Public Health. 2019;77(1):6. doi:10.1186/s13690-019-0330-8

36. Karyotaki Eirini, Smit Yolba, Cuijpers Pim, et al. The Long-Term Efficacy of Psychotherapy, Alone or in Combination with Antidepressants, in the Treatment 
of Adult Major Depression. Belgian Health Care Knowledge Centre (KCE); 2014.

37. Rhodes A, Ferdinande P, Flaatten H, Guidet B, Metnitz PG, Moreno RP. The variability of critical care bed numbers in Europe. Intensive Care Med. 2012;38(10):1647-1653. doi:10.1007/s00134-012-2627-8

38. Korcok M. AIDS hysteria: a contagious side effect. CMAJ Can Med Assoc J J Assoc Medicale Can. 1985;133(12):1241-1248.

39. Sohn S, Rees P, Wildridge B, Kalk NJ, Carter B. Prevalence of problematic smartphone usage and associated mental health outcomes amongst children and young people: a systematic review, meta-analysis and GRADE of the evidence. BMC Psychiatry. 2019;19(1):356. doi:10.1186/s12888-019-2350-x

40. Shao C, Hui P-M, Wang L, et al. Anatomy of an online misinformation network. PloS One. 2018;13(4):e0196087. doi:10.1371/journal.pone.0196087

41. Colloca L, Barsky AJ. Placebo and Nocebo Effects. N Engl J Med. 2020;382(6):554-561. doi:10.1056/NEJMra1907805

42. Mommaerts JL, Devroey D. The placebo effect: how the subconscious fits in. Perspect Biol Med. 2012;55(1):43-58. doi:10.1353/pbm.2012.0005

43. Allaerts W, Chang TW. Skewed Exposure to Environmental Antigens Complements Hygiene Hypothesis in Explaining the Rise of Allergy. Acta Biotheor. 2017;65(2):117-134. doi:10.1007/s10441-017-9306-7

44. Lambrecht $B N$, Hammad $\mathrm{H}$. The immunology of the allergy epidemic and the hygiene hypothesis. Nat Immunol. 2017;18(10):1076-1083. doi:10.1038/ni.3829

45. van Schaik $A$, van Marwijk $H$, Adèr $H$, et al. Interpersonal psychotherapy for elderly patients in primary care. Am J Geriatr Psychiatry Off J Am Assoc Geriatr Psychiatry. 2006;14(9):777-786. doi:10.1097/01.JGP.0000199341.25431.4b

46. Annemans L, Brignone M, Druais S, De Pauw A, Gauthier A, Demyttenaere K. Cost-Effectiveness Analysis of Pharmaceutical Treatment Options in the First-Line Management of Major Depressive Disorder in Belgium. Pharmacoeconomics. 2014;32(5):479-493. doi:10.1007/s40273-014-0138-x 


\section{ACKNOWLEDGEMENTS}

Funding: none

Author contributions: FF conceived the study, performed the analysis, wrote manuscript versions; SB assisted with data and reference gathering; reviewed manuscript versions, and provided methodological assistance; SDP reviewed manuscript versions.

Competing interests: Authors declare no competing interests.

Data and materials availability: All data are available from the authors;

\section{Appendix 1}

\section{TABLE 1 DATA SEARCH RESULTS}

data

mortality of flu in Belgium

representative studies that checked how many people are infected

age distribution of Covid hospital admissions

Belgian criterion to count a covid hospitalization

governments' scientific recommendation reports

Belgian COVID-19 immunity

recent mortality data (date of birth, date of death, gender, nationality, place of residence and place of found

no

no

no

no

no

no

no 
death) for Belgium

COVID-19 intensive care yes

COVID-19 hospitalisations in EU yes

recent problematic cocaine use and alcohol no

consumption

new poverty (e.g living wages) in Belgium no

new family and partner violence no

new anxiety and depression (Belgium, Sweden) yes

TABLE 2: CONTACTS WITH TOPIC AND RESULTS

$\begin{array}{llllc}\text { date } & \text { contact } & \text { topic } & \text { question } & \begin{array}{c}\text { helpful } \\ \text { answe }\end{array} \\ \text { r? }\end{array}$




\begin{tabular}{|c|c|c|c|}
\hline $\begin{array}{l}10 / 04 \\
/ 20\end{array}$ & $\begin{array}{l}\text { Sciensano national } \\
\text { public health institute } \\
\text { of Belgium }\end{array}$ & data & $\begin{array}{l}\text { data on the age distribution } \\
\text { of Covid hospital } \\
\text { admissions }\end{array}$ \\
\hline $\begin{array}{l}10 / 04 \\
120\end{array}$ & $\begin{array}{l}\text { fellow scientist } \\
\text { advising Belgian } \\
\text { government }\end{array}$ & $\begin{array}{l}\text { relevant } \\
\text { studies }\end{array}$ & $\begin{array}{l}\text { which representative } \\
\text { studies that check how } \\
\text { many people are infected }\end{array}$ \\
\hline $\begin{array}{l}14 / 04 \\
120\end{array}$ & $\begin{array}{l}\text { Sciensano national } \\
\text { public health institute } \\
\text { of Belgium } \\
\text { (info-coronavirus } \\
\text { channel) }\end{array}$ & $\begin{array}{l}\text { methodolo } \\
\text { gical } \\
\text { question }\end{array}$ & $\begin{array}{l}\text { How does Sciensano count } \\
\text { a covid hospitalization? } \\
\text { What is the criterion? }\end{array}$ \\
\hline
\end{tabular}

16/04 Sciensano national follow up follow up: who can answer no

/20 public health institute my question?

of Belgium

16/04 Sciensano national

methodolo How does Sciensano count no

/20 public health institute of Belgium

gical

a covid hospitalization?

question What is the criterion?

19/04 fellow scientist

relevant most recent scientific

no

/20 associated with

studies

recommendation report for

university

the government concerning

the covid epidemic

$\begin{array}{ll}25 / 04 & \text { fellow scientist } \\ 120 & \begin{array}{l}\text { associated with } \\ \text { university }\end{array} \\ 28 / 04 & \text { fellow scientist at } \\ / 20 & \begin{array}{l}\text { Sciensano national } \\ \text { public health institute } \\ \text { of Belgium }\end{array}\end{array}$

relevant Where can I read your

no

studies recent research referred to

in the press regarding the

estimate of Covid immunity?

28/04 fellow scientist at methodolo

/20 Sciensano national gical

public health institute question

Where can I read the full

no

text of the study?

of Belgium

full text

text of the study?

How representative is the no approach for the Belgian

population? To what extent do you measure immunity in $<18$ year olds? How do you approach corrections to representational? 


\begin{tabular}{|c|c|c|c|}
\hline $\begin{array}{l}29 / 04 \\
/ 20\end{array}$ & $\begin{array}{l}\text { Eurosurveillance: } \\
\text { European journal on } \\
\text { infectious disease } \\
\text { surveillance, } \\
\text { epidemiology, } \\
\text { prevention and } \\
\text { control }\end{array}$ & data & $\begin{array}{l}\text { I want to re-analyse this } \\
\text { study. Where can I find the } \\
\text { data? }\end{array}$ \\
\hline $\begin{array}{l}29 / 04 \\
/ 20\end{array}$ & $\begin{array}{l}\text { fellow scientist at } \\
\text { Sciensano national } \\
\text { public health institute } \\
\text { of Belgium }\end{array}$ & data & $\begin{array}{l}\text { Where can I find solid } \\
\text { figures on the flu epidemic } \\
\text { of } 2014-2015 ?\end{array}$ \\
\hline $\begin{array}{l}30 / 04 \\
/ 20\end{array}$ & $\begin{array}{l}\text { EuroMOMO: } \\
\text { European monitoring } \\
\text { of excess mortality } \\
\text { for public health } \\
\text { action }\end{array}$ & data & $\begin{array}{l}\text { I want to re-analyse this } \\
\text { study. Where can I find the } \\
\text { data? }\end{array}$ \\
\hline
\end{tabular}

30/04 Eurosurveillance: follow up What other options for a no /20 European journal on infectious disease surveillance, epidemiology, prevention and control

\begin{tabular}{|c|c|}
\hline $\begin{array}{l}01 / 05 \\
/ 20\end{array}$ & $\begin{array}{l}\text { fellow scientist } \\
\text { associated with } \\
\text { university }\end{array}$ \\
\hline$/ 05$ & Federal Public \\
\hline 20 & Service Economy \\
\hline
\end{tabular}

\begin{tabular}{|c|c|}
\hline data & $\begin{array}{l}\text { I want to re-analyse this } \\
\text { study. Where can I find the } \\
\text { data? }\end{array}$ \\
\hline data & $\begin{array}{l}\text { Where and how can I find } \\
\text { recent mortality data for } \\
\text { Belgium }\end{array}$ \\
\hline data & $\begin{array}{l}\text { Where can I find data on } \\
\text { the most recent deaths in } \\
\text { Belgium? }\end{array}$ \\
\hline data & $\begin{array}{l}\text { Where can I download the } \\
\text { data (date of birth, date of } \\
\text { death, gender, nationality, } \\
\text { place of residence and } \\
\text { place of death) from the }\end{array}$ \\
\hline
\end{tabular}

$\begin{array}{llll}\begin{array}{l}02 / 05 \\ 120\end{array} & \begin{array}{l}\text { Federal Public } \\ \text { Service for Domestic } \\ \text { Affairs }\end{array} & \text { data } & \begin{array}{l}\text { Where can I find data on } \\ \text { the most recent deaths in } \\ \text { Belgium? }\end{array} \\ \begin{array}{ll}\text { 02/05 } & \begin{array}{l}\text { Sciensano national } \\ \text { public health institute } \\ \text { of Belgium }\end{array}\end{array} \quad \text { data } & \begin{array}{l}\text { Where can I download the } \\ \text { data (date of birth, date of } \\ \text { death, gender, nationality, } \\ \text { place of residence and } \\ \text { place of death) from the }\end{array}\end{array}$


MoMo stat

$\begin{array}{ll}\text { 04/05 } & \begin{array}{l}\text { European Centre for } \\ \text { /20 }\end{array} \\ & \begin{array}{l}\text { Disease Prevention } \\ \text { and Control }\end{array} \\ 04 / 05 & \text { Helpdesk Federal } \\ / 20 & \begin{array}{l}\text { Public Service for } \\ \text { Domestic Affairs }\end{array}\end{array}$
04/05 fellow scientist
/20 associated with university

04/05 Belgian Helpline for /20 addictions
04/05 Poverty advocacy /20 organization
05/05 Federal Public /20 Planning Service (PPS) Social Integration
05/05 Federal Public /20 Service Economy
05/05 flemish association data /20 for cities and municipalities: welfare unit

\begin{abstract}
data
\end{abstract}
data

data

data

data

data
Where can I download the no COVID-19 hospitalisations for European countries?

Where can I download the no data (date of birth, date of death, gender, nationality, place of residence and place of death) from the MoMo stat

I am looking for recent no figures on cocaine use and alcohol

the number of reports of no problem drug use during the current crisis

Do you have an estimate of no the number of new poor in Belgium due to this lockdown?

What are the most recent no data about the number of applications for living wages in Flanders / Belgium during the lockdown?

What service can I contact no for the dates (place of death at home, hospital, public road, institution) of the death certificate?

What are the most recent no data about the number of applications for living wages in Flanders during the lockdown? 


\begin{tabular}{|c|c|c|c|c|}
\hline $\begin{array}{l}05 / 05 \\
120\end{array}$ & $\begin{array}{l}\text { flemish association } \\
\text { for cities and } \\
\text { municipalities: } \\
\text { welfare unit }\end{array}$ & data & $\begin{array}{l}\text { What are the most recent } \\
\text { data about the number of } \\
\text { applications for living wages } \\
\text { in Flanders during the } \\
\text { lockdown? }\end{array}$ & no \\
\hline $\begin{array}{l}05 / 05 \\
120\end{array}$ & $\begin{array}{l}\text { fellow scientist } \\
\text { associated with } \\
\text { university }\end{array}$ & data & $\begin{array}{l}\text { follow up: I am looking for } \\
\text { recent figures on cocaine } \\
\text { use and alcohol }\end{array}$ & no \\
\hline $\begin{array}{l}05 / 05 \\
120\end{array}$ & $\begin{array}{l}\text { fellow scientist } \\
\text { associated with } \\
\text { university }\end{array}$ & data & $\begin{array}{l}\text { What day was the Swedish } \\
\text { peak cumulated } \\
\text { hospitalisations and what } \\
\text { were the exact numbers? }\end{array}$ & yes \\
\hline $\begin{array}{l}05 / 05 \\
120\end{array}$ & $\begin{array}{l}\text { fellow scientist } \\
\text { associated with } \\
\text { university (by phone) }\end{array}$ & $\begin{array}{l}\text { peer } \\
\text { advice }\end{array}$ & $\begin{array}{l}\text { info on familiy and partner } \\
\text { violence }\end{array}$ & yes \\
\hline $\begin{array}{l}06 / 05 \\
120\end{array}$ & $\begin{array}{l}\text { fellow scientist at } \\
\text { Sciensano national } \\
\text { public health institute } \\
\text { of Belgium }\end{array}$ & data & $\begin{array}{l}\text { We conduct research into } \\
\text { mental well-being. And } \\
\text { quickly search for even } \\
\text { more data }\end{array}$ & yes \\
\hline
\end{tabular}

$\begin{array}{ll}06 / 05 & \text { fellow scientist at } \\ 120 & \text { Sciensano national } \\ & \text { public health institute } \\ & \text { of Belgium }\end{array}$

06/05 fellow scientist

/20 associated with university

06/05 fellow scientist at /20 Sciensano national public health institute of Belgium

07/05 Federal Public /20 Service Economy data In our research, we want to limit overlap in counts.

Could you therefore give me the $\%$ of people (with population $\mathrm{N}$ ) of...

peer advice

peer advice

When do you estimate the results of the second round of the survey?

data

That's nice to know,.... but no as a researcher I am looking for the death certificate dates for the period March / April

yes advice on estimated data no yes 


\begin{tabular}{|c|c|c|c|}
\hline $\begin{array}{l}07 / 05 \\
/ 20\end{array}$ & $\begin{array}{l}\text { fellow scientist at } \\
\text { National public health } \\
\text { institute of Sweden }\end{array}$ & $\begin{array}{l}\text { relevant } \\
\text { studies }\end{array}$ & $\begin{array}{l}\text { In Belgium we surveyed } \\
\text { peoples' anxiety and } \\
\text { depression levels. What } \\
\text { research is available for } \\
\text { your country? }\end{array}$ \\
\hline $\begin{array}{l}08 / 05 \\
/ 20\end{array}$ & $\begin{array}{l}\text { fellow scientist at } \\
\text { Sciensano national } \\
\text { public health institute } \\
\text { of Belgium }\end{array}$ & data & $\begin{array}{l}\text { compare figures with the } \\
\text { major health survey of } 2018\end{array}$ \\
\hline $\begin{array}{l}11 / 05 \\
/ 20\end{array}$ & $\begin{array}{l}\text { fellow scientist } \\
\text { associated with } \\
\text { university }\end{array}$ & follow up & $\begin{array}{l}\text { What are the results of your } \\
\text { research on partner } \\
\text { violence? }\end{array}$ \\
\hline $\begin{array}{l}12 / 05 \\
120\end{array}$ & $\begin{array}{l}\text { European Centre for } \\
\text { Disease Prevention } \\
\text { and Control }\end{array}$ & data & EU hospitalisations data \\
\hline
\end{tabular}

\section{Appendix 2}

\section{EFFECTIVENESS EVIDENCE}

\begin{tabular}{|l|l|l|}
\hline Quality of Life & $\begin{array}{l}\text { Quality of Life } \\
\text { SMD* }(95 \% \mathrm{Cl})\end{array}$ & outcome follow-up(yrs) \\
\hline depression psychotherapy & $0.20(0.03-0.36)^{36}$ & 1 \\
\hline${ }^{*}$ Quality of life outcome & \\
\hline
\end{tabular}

ECONOMIC EVALUATION

\section{Target population}

people with newly diagnosed depression and / or anxiety during lockdown 


\section{Perspective}

We conducted this analysis from the perspective of the Belgium Ministry of Health and long term care at 1 year with symptoms in remission.

\section{Interventions}

The analysis examined the cost-effectiveness of general psychotherapy (PT) for depression.

The baseline comparator is care as usual (TAU) or waiting list. Within TAU, people could receive any appropriate medical care during the course of the study on a naturalistic basis, including pharmacotherapy and/or psychological therapy, as deemed necessary by the clinician.

depression PT: 1 visit to GP + 27 sessions clinical psychologist $(\mathrm{CP})$ (5 months acute treatment (20 session), 7 months follow up ( 7 session $))^{45}$

\section{Outcomes}

QALYs, direct medical costs, cost per QALY gained

\section{Time horizon}

1 year

\section{Main assumptions}

care as usual is arbitrarily valued as 7 visits to a GP

$50 / 50$ ratio of $\mathrm{mild} / \mathrm{major}$ depression diagnoses 


\section{Cost parameters}

value HLY: 40,000€

price psychotherapy/session: $80 €$

price general practitioner (GP)/session: $23 €$

price psychiatrist/session: $56 €$

depression medication/year: $1113 €^{46}$ 